\title{
2003 年度日本地理学会総会記事
}

\author{
(於・日本大学文理学部)
}

2003 年度総会は 5 月 10 日（土） 13 時〜 13 時 30 分, 日本大学文理学部百周年記念館にて開催. 佐野 総務委員会委員長の開会の辞の後, 野上道男会長の 挨拶があり, 総会議長に阿部 隆会員を選出し, 書 記を橋詰総務専門委員に委嘱した，続いて，総会成 立の確認が行われた. 当日の参加者は 27 名, 委任 状は 86 名の合計 103 名となり, 総会構成員（136 名）の過半数の参加を得て成立することが報告され た.

\section{I 審議事項}

議案 12002 年度事業報告

まず, 谷内理事長より, 2002 年度事業報告がさ れた（決算報告と一括審議の確認がされた）。今回 から事業年度が 3 月 31 日までとなることから, 事 業や決算に従来と違う点が含まれることが確認され た. 集会は, 学術大会が 3 回（日本大学, 金沢大学, 東京大学）実施された。出版物は, 地理学評論 14 冊 (938 ページ), 発表要旨集 3 冊 (777ページ), 海外地域研究叢書 3 冊であった。研究グループは, 18 グループが活動を行った. 会議等では, 総会 3 回, 代議員会 3 回, 理事会 13 回が開催されたほか, 専門委員会と各種委員会がそれぞれ9委員会開催さ れた旨の報告があり, 議案 2 と一括審議され，拍手
で承認された。

議案 22002 年度決算報告

田林財務専門委員会委員長より, 決算報告書に基 づいて 2002 年度決算報告がされた。事業報告と同 様, 会計年度は平成 14 年 3 月 11 日から平成 15 年 3 月 31 日までとなっている旨の説明があり, 収支 計算書総括表, 正味財産增減計算表総括表, 貸借対 照表総括表, 収支計算書 (一般会計, 学術大会関係 特別会計), 正味財産增減計算書（学術大会関係特 別会計, 一般会計), 貸借対照表 (一般会計), 財産 目録（一般会計）の説明がなされ, 議案 1 と一括審 議され，拍手で承認された。

議案 32003 年度予算の補正

田林財務専門委員会委員長より, 2003 年度 (平 成 15 年 4 月 1 日から平成 16 年 3 月 31 日）の予算 の補正について, 第一次補正予算書 (一般会計, 学 術大会関係特別会計, 選挙管理 - 名簿作成費積立 金）に基づき説明がなされ，拍手で承認された。

\section{II その他}

なし.

以上の議事を終了し, 議長による書記の解任と議 長の解任が行われた後, 佐野総務専門委員長の閉会 の辞をむって 2003 年度総会を終了した。 
※※※※※※※※※※※※※※※※※※※※※※※※※※※※※※

※

$※$

※ 決 算 報告 書

※

※

※※※※※※※※※※※※※※※※※※※※※※※※※※※※※※

自 平成 14 年 3 月 11 日

至 平成 15 年 3 月 31 日

住 所 東京都文京区弥生2丁目4番16号

学会センタービル3階

日本地理学会

收支計算書 総括表

平成14年3月11日から平成15年3月31日まで

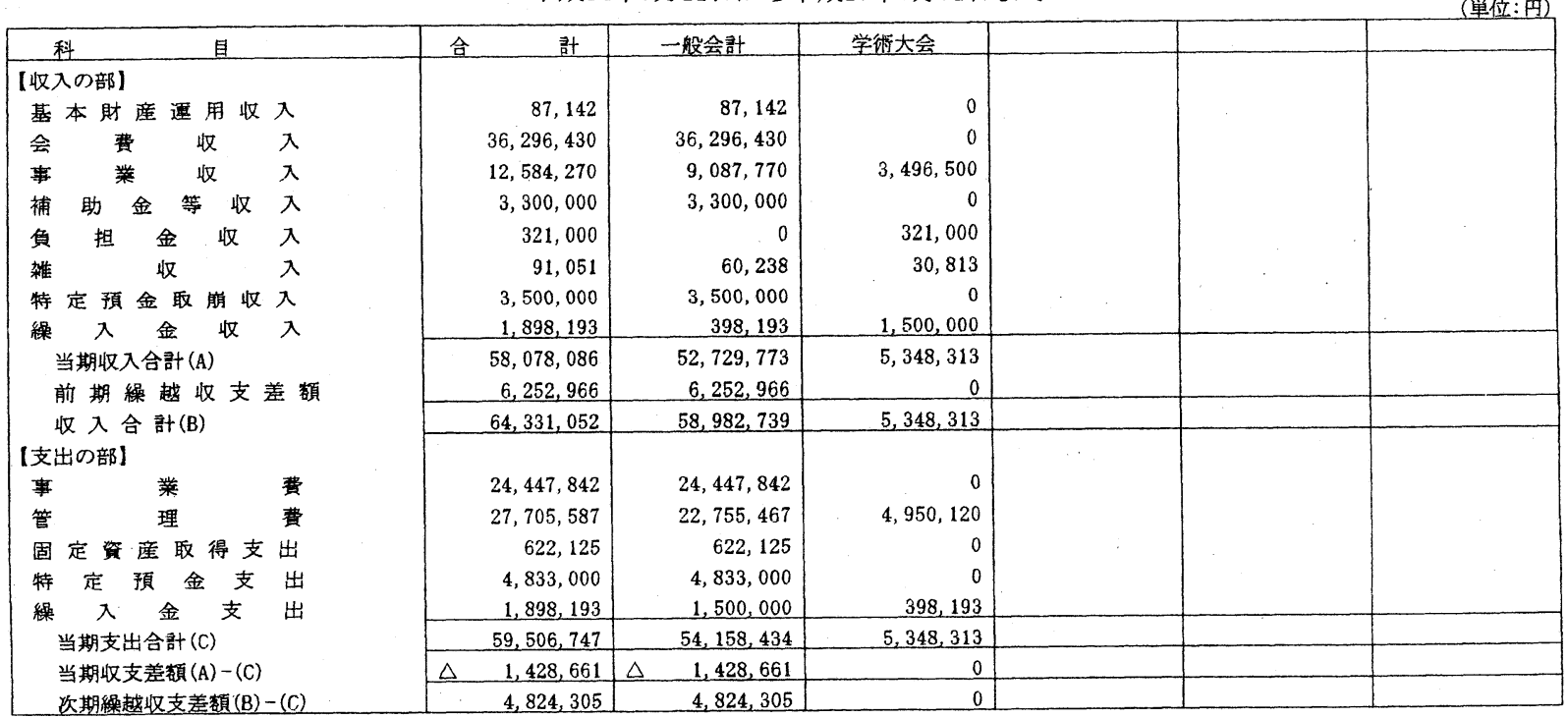


正味財座增诚計算表総括表

平成14年3月11日から平成15年3月31日まで

(単位:丹)

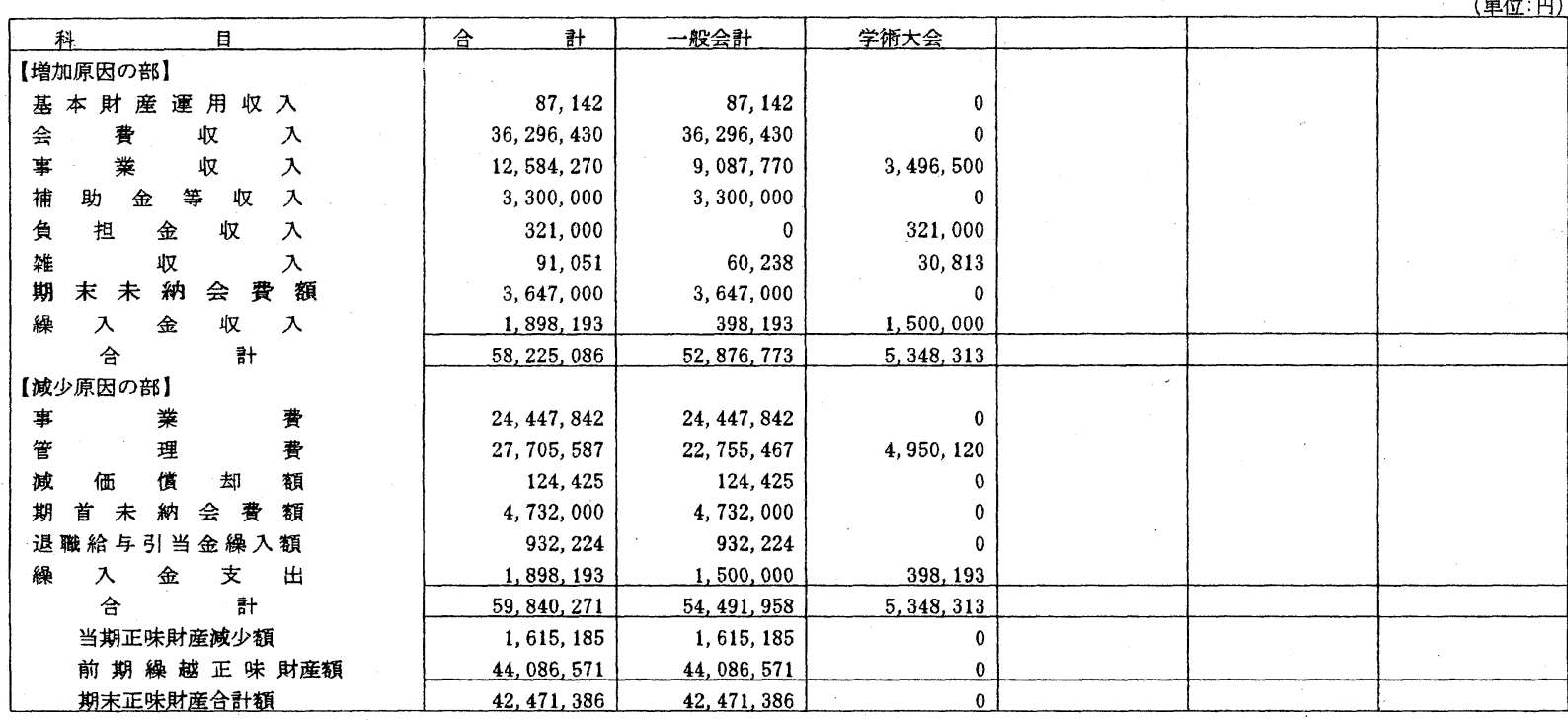

貸 借 対 照 表 総 括 表

平成15年3月31日現在

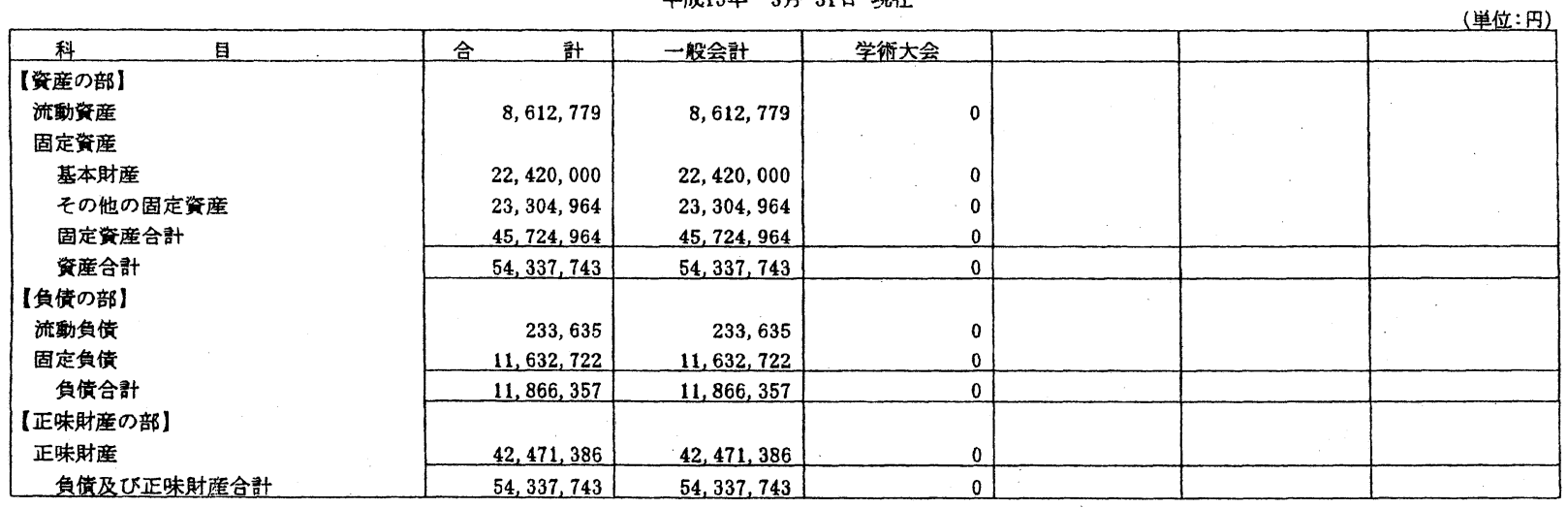




\section{会 告}

\section{4 年度春季学術大会のお知らせ (第 2 報)}

2004 年度の日本地理学会春季学術大会を, 下記の通り東京経済大学において開催します。本大会で発表を 希望する会員は，次ページ 7, 拉よび巻末の「作成要領（見本）」に従って完全な版下原稿を作成し，所定の 期日までに申し込んで下さい.「作成要領」に準拠していない発表申し込みは受理できませんので御注意下さ い.

1. 期 日 2004 年 3 月 27 日（土）〜3月 28 日（日）（ただし総会・代議員会は 3 月 26 日（金)）

2. 会 場 東京経済大学

3. 連絡先 $\overline{7} 185-8502$ 東京都国分寺市南町 1-7-34

東京経済大学コミュニケーション学部

山田晴通 研究室

電話 042-328-7923 e-mail:yamada@tku.ac.jp

4. 日 程 3 月 27 日 (土) シンポジウム, 一般発表, 鮁親会

3 月 28 日（日） シンポジウム, 一般発表, 研究グループ

3 月 29 日（月）巡検

\section{5. 一般発表の形式と方法}

一般発表の形式には，(1)口頭発表，(2)ポスター発表，(3)ビデオ・コンピュータ発表があります。どの形式で 屯発表としてはまったく同格です.

いずれの形式であっても，発表を希望される方は，大会実行委員会ホームページ（http://camp.ff.tku.ac. jp/ajg2004.html）にある「発表予定者への打知らせ」を熟読の上で, 準備を進めて下さい.

1） 口頭発表 口頭発表は 1 人につき 1 題とします. ただし，シンポジウム発表，ポスター発表あるいはビ デオ・コンピュータ発表との重複，本人が口頭発表や説明を行わない連名発表との重複はかまいません， 口頭 発表は発表時間 15 分, 質疑応答 4 分ですので, 必ず 15 分でまとまるように準備して下さい. 大会の円滑な運 営のために発表時間を固定しますので, 各自の発表の日時は後日発表されるプログラムを参照して下さい. 大 会運営の合理化のため, 発表は要旨集と OHP の使用を原則とし, 会場での資料の配布は御遠慮下さるよう強 く要望します.

なお，今大会では，試行的にコンピュータ用液晶プロジェクターの利用を一定の範囲で受け付けます，詳細 は「発表予定者への㧍知らせ」を御覧下さい.

2）ポスター発表 ポスター発表は 1 人につき 1 題とします. ただし, シンポジウム発表, 口頭発表との重 複, 本人が口頭発表や説明を行わない連名発表との重複はかまいません. ポスター発表は展示場所と 1 2 時 間程度の質疑応答の時間帯を指定しますので, この間に展示の場所で 20 分以上の口頭説明を行って下さい. ポスターの大きさの標準は $90 \mathrm{~cm} \times 90 \mathrm{~cm} \times 2$ 枚です．発表スペースに制約がありますので，要望に添えない こともあります．会場での資料・別刷の配布は自由です．詳細は「発表予定者へのお知らせ」を御覧下さい．

3) ビデオ・コンピュータ発表 ビデオ・コンピュータ発表は 1 人につき 1 題とします.ただし，シンポジ ウム発表, 口頭発表との重複, 本人が口頭発表や説明を行わない連名発表との重複はかまいません。ビデオ・ コンピュータ発表は設置場所と 1 2 時間程度の質疑応答の時間帯を指定しますので，この間に展示の場所で 20 分以上の口頭説明を行って下さい. 会場での資料・別刷の配布は自由です. 詳細は「発表予定者へのお知 らせ」を御覧下さい。

\section{6. 一般発表の申し込み方法}

一般発表は発表要旨集版下原稿の受付けをむって申し込みとします. 発表希望者は下記版下原稿の作成方法 により作成したオリジナル 1 部とそのコピー 2 部に, 本号綴込みの発表申し込み用紙 $(\mathbf{A} \cdot \mathbf{B}$ 片もしくは $\mathbf{B} \cdot$ 
$\mathrm{C}$ 片，今回から様式に一部変更あり）を添えて，1月22 日（木）必着で， テ113-0032 東京都文京区弥生 2-4 -16 学会センタービル 3 階, 日本地理学会集会専門委員会あて送付して下さい. 下記「発表要旨集版下原稿 の作成要領」に準拠していない原稿は受理できません，締切り直後にプログラム編成と発表要旨集の編集を行 いますので, 締切日を厳守して下さい. 整理の都合上, 一般発表の版下原稿は発表ごとに別々の封筒で送って 下さい，ただし，シンポジウム発表と下記の「グループ発表」はその限りではありません。なお，事務局到着 後の版下原稿の差し替えは受け付けませんので，送付前に十分な確認をお願いします．

関連する複数の発表を連続する時間帯（口頭発表）あるいは場所（ポス夕ー発表）にまとめることを希望す るグループは，その責任者が全員の版下原稿を取りまとめ，一括して送って下さい．この場合封筒に「グルー プ発表」と記し, 発表順序の案を同封して下さい.

\section{7. 発表要旨集版下原稿の作成要領}

版下原稿の文章はワープロ作成とします．仕上がり A4 版になるよう版下原稿を原寸で直接写真製版します. 版下原稿のスタイルと作成方法の要点は次の通りです.

（ア）用紙は A4 サイズ $(210 \mathrm{~mm} \times 297 \mathrm{~mm})$ で縦長, 横書きとする.（イ）ページ数は 1 ページとする. （ウ）上下 $25 \mathrm{~mm}$ ，左右 $18 \mathrm{~mm}$ の余白を取り，文字・図表を必ずこの範囲に収める.（エ）2 段組とし，段間 を約 $8 \mathrm{~mm}$ 取る.（オ）タイトル（和文, 英文), 著者名, 所属 (和名, 英文), キーワード 4 6 個 (和文, 英文)，本文 (文章と図表）の順番で書く。レイアウトは下記の図を参考にする。（カ）本文 (和文) の文字は 8 9 9゚イント, タイトル 12 ポイント, サブタイトルがある場合には $10 \sim 12$ ポイント, 氏名・所属は 10 ポイ ントとする (和文)。（キ）図は原図，コンピュータのプリント，コピーのいずれであよいが，鮮明なすのを用 いる.

詳細については，本号巻末の「発表要旨集版下原稿の作成要領（見本)」を参照して下さい，な㧍版下原稿 は原則として返却しません。

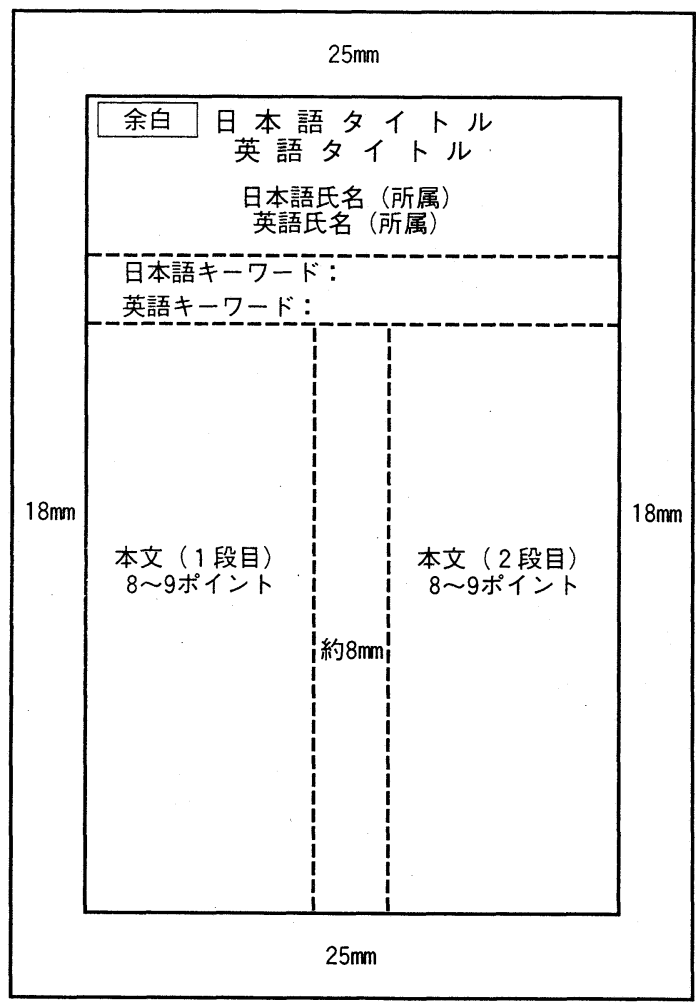




\section{J-STAGE 発表登録システムへの登録}

日本地理学会では, 2003 年度春季大会よりインターネットの webによる発表登録システムを導入いたしま した．このシステムを利用すると，発表内容が学術情報データベースに登録され広く周知されるので, 発表者 個人としてあまた学会としても大いにメリットがあります. 2003 年度秋季大会より，発表申し込み者には webによる発表登録をあらかじめ行っていただくことを原則としております．今大会での発表を希望する会 員は，あらかじめwebによる発表登録を行った上で，その際にweb から交付された登録番号を「発表申し込 み票 A 片または C片」の該当欄に記入し，版下原稿とと屯に学会事務局宛に郵送して下さい。なお，正式な 発表申し込みはwebではなく, 従来ど扔り郵送で発表申し込み票と要旨原稿を扔送りいただくことによって 受け付けますのでお間違えのないようお願いいたします。

web による発表登録期間は 1 月 6 日から 1 月 22 日を予定しております，発表登録用 webには，日本地理 学会ホームページ (http://wwwsoc.nii.ac.jp/ajg/) から入ることができますので，画面の指示に従って登録 を行って下さい，なお，登録画面の備考欄には発表内容に関わることのみ御記入下さい，発表順序の希望など のプログラム編成に関わる事項を記入してあ編成会議に伝わりませんので御注意下さい.

\section{9. 研究グループの会場申し込み}

研究グループなどの集会は，3 月 28 日（日） 13 時〜 17 時の間に設定する予定です．部屋を用意しますので， 開催希望のグループは，グループ名，責任者氏名，連絡先，開催希望時間，参加見込み人数を文書で（書式は 自由), 1 月 22 日（木）までに，日本地理学会集会専門委員会あて申し込んで下さい. 会場数が少ないので, 時間帯については御希望に沿えない場合むあります，会場校ではグループでの研究発表に関わる準備はしませ ん. 会場校の負担軽減抢よび一般発表の充実に御協力下さい.

\section{「海外における地理学評論の引用状況の調査」に関する御協力のお願い}

地理学評論の刊行にあたっては，日本学術振興会科学研究費補助金の助成を受けています．補助金申請にあ たり，「地理学評論和文号および英文号掲載論文の，海外学術雑誌（2000 2001 年）での引用状況」に関する 情報を必要として抢ります，学会で検索に使用しておりますデータベースの Science Citation Index (SCI), Social Science Citation Index（SSCI）には，すべての学術雑誌がソースジャーナルとして採録されている 訳ではありませんので，採録漏れの雑誌で引用されているものについては学会事務局でも捕捉できません．完 璧を期すには，会員の皆様からどうしても（自己）申告していただく必要があります.引続き十分な額の補助 金の配分を受けるためにも，お心当たりの方は，11月 15 日までに，掲載された雑誌名（できましたら略記で はなくフルタイトル), 発行年 (巻号), 引用論文のタイトル, 引用されている地理学評論の論文の著者名とそ の巻号を，日本地理学会あてにお知らせ下さるよう御協力をお願い申し上げます.

\section{平成 16 年度科学研究費補助金研究成果公開促進費「研究成果公開発表 (B)」および 「研究成果公開発表 $(\mathbf{C}) 」$ 」募集について}

文部科学省研究振興局学術研究助成課から上記の件につきまして，通知がありましたので御関心のある方は， 文部科学省研究振興局学術研究助成課までお問い合わせ下さい．また，詳細・申請用紙は文部科学省ホームぺ ージ URL http://www.mext.go.jp/a_menu/shinkou/hojyo/koubotop.htmよりダウンロードできます. なお，来年度も同じ要領で募集があると思われますので，シンポジゥム等を御計画の会員は，早めに御準備下 さい.

・研究成果公開発表 (B) : 1. 趣旨 学会や民間学術研究機関などが, 最新の研究動向などの普及のため, 青 少年や社会人を対象として開催するシンポジゥム，学術講演会の実施に必要な経費を助成する．2．実施の方 法＼cjkstart開催日は原則として 1 日とする．参加費は徵収しないことなど． 3. 実施の期間 2004 年 7 月 1 日〜2005 年 3 月 31 日. 4. 申請限度額 1 件 150 万以内.

-研究成果公開発表 $(C) ： 1$. 趣旨 学会が主催し, 諸外国の研究者の参加を得て, 開催する国際会議実施に 必要な経費を助成. 2. 実施の方法 人文・社会科学, 自然科学を対象とし, 開催日は原則として 2 日以上と 
する．参加者は 500 人内外，そのうち 10 分の 1 程度の外国人研究者が含まれていることなど． 3 ．実施の期間 2004 年 7 月 1 日 2005 年 3 月 31 日（なお，平成 16 年度に準備を行い平成 17 年度の開催予定の場合について あ申請できる)。

研究成果公開発表 (B) および (C) 申請方法 計画調書（用紙については, 文部科学省研究振興局学術研 究助成課に御請求いただくか，上記ホームページよりダウンロードして下さい）を 15 部作成の上，11月 17 日（月） 11月 20 日（木）に，文部科学省研究振興局に提出すること.

\section{平成 16 年度東京大学海洋研究所共同利用研究公募}

1. 応募資格 国・公・私立大学拉よび国・公立研究機関の研究者ならびにこれに準ずる者で，海洋の基礎的 研究を目的とするすの. 2. 共同利用研究の種別 (1) 研究船 研究船淡青丸 (610 総トン) 主に近海の研究 航海を行う.（2）研究集会 海洋研究所（中野キャンパスの施設を利用）での 1 2 日間のシンポジゥム. (3) 外来研究員 所外の研究者が本所に滞在して研究を行う便宜を提供. (4) 国際沿岸海洋研究センター 1) 外 来研究員 センターに滞在して研究を行う便宜を提供. 2) 研究集会“少人数の研究者による討論集会など. 3. 申込期限 11 月 28 日 (金). 4. 問合せ 公募要領および各申込書類は http://www.ori.u-tokyo.ac.jp に掲載 されています. 東京大学海洋研究所 総務課海務・共同利用掛 テ164-8639 中野区南台 1-15-1 電話 035351-6354，6355 FAX 03-5351-6836 国際沿岸海洋研究センター †028-1102 岩手県上閉伊郡大槌町赤浜 2-106-1 電話 0193-42-5611 FAX 0193-42-3715 平成 17 年度の白鳳丸の公募は, 平成 16 年 6 月上旬加 行う.

\section{各種学術賞・研究奨励金候補者の公募について}

\section{平成 16 年度「とやま賞」候補者募集}

1. 対象 富山県出身または富山県在住の者. 学術研究，発明発見（技術開発・応用を含む），芸術文化，又ポ 一ッなどの分野において，すぐれた業績を挙げ，かつ，将来の活躍が期待される個人または団体．なお，年齢 は原則として 45 歳（2004 年 5 月 9 月現在）までとするが，人文・社会科学系についてはこの限りではない. また，大学・研究機関等にあっては助教授クラスまでとし，教授は含まない．2．賞 奨励金 100 万円． 3. 申 請 詳細については，財団法人富山県ひとづくり財団のホームページ（URL：http://www.t-hito.or.jp）を 御覧下さい，推薦を希望される会員は，所定の用紙を上記ホームページよりダウンロードし必要事項を記入の 上，11月28日（金）までに理事会あてに御提出下さい．理事会にて推䴢を決定いたします.

\section{4 年度多摩川およびその流域の環境浄化に関する研究募集}

1. 研究対象 1）産業活動または住生活と多摩川およびその流域との関係に関する調查・研究，2）排水・廃 棄物などによる多摩川の污染の防除に関する調査・研究，3）多摩川およびその流域における水の利用に関す る調查・研究，4）多摩川をめぐる自然環境の保全，回復に関する調查・研究. 2. 締切 2004 年 1 月 15 日 (木). 3. 申請用紙請求先・問合せ先 応募要項・申請書は 200 円切手同封の上，下記あて御請求下さい，木 ームページからもダウンロードできます， T150-0002 渋谷区渋谷 1-16-14 渋谷地下鉄ビル内 財団法人之 うきゅう環境浄化財団 電話 03-3400-9142 FAX 03-3400-9141 詳細はホームページ URL http://home. q07.itscom.net/tokyuenv 


\section{公示}

日本地理学会選挙管理委員会

委員長 菅野峰明

日本地理学会会則抢よび役員・代議員選挙の規程に従い，2004 2005 年度を任期とする会長・理事・監事 および代議員の選挙を下記の日程で行う予定です.

会長候補者・理事予定者・監事予定者選挙

2003 年 (以下, 同年) 10 月 9 日 投票用紙発送

10 月 23 日 投票締切（当日，必着）

10 月 25 日 開票

会長予定者・代議員予定者選挙

11 月 22 日 投票用紙発送

12 月 12 日 投票締切（当日，必着）

12 月 13 日 開票

なお, 理事長予定者 1 名打よび常務理事予定者 2 名の選挙については, 新理事予定者が決定した後, 新理事予 定者での互選となりますので，現時点での日程公示はいたしません，今回の選挙における当選者は，総会にお いて正式に選任されます。

\section{日本地理学会賞（優秀賞）候補者推萀のお願い}

日本地理学会賞受賞候補者選考委員会

委員長 岩田修二

日本地理学会賞受賞候補者選考委員会では，2002 年度から「日本地理学会賞 (優秀賞) 」，「同 (奨励賞) 」, 「同（特別賞）」のうちの優秀賞については，地理学の各分野で顕著な研究業績を挙げた者を，会員のみなさま からの自薦・他薦によって御推薦いただき選考しております．選考委員会は，みなさまから推薦された者の中 から，受賞候補者若干名を年度末までに理事会に報告いたします．受賞者には賞状が授与されます．

すでに日本地理学会には, 若手会員を対象にした奨励賞がありますが, 優秀賞は若手だけではなく, より広 い年齢層を対象とするすのです.

下記の要領で受賞候補者の御推薦をいただきますよう，会員各位にお願い申し上げます.

\section{記}

1. 推薦の対象となる者

2003 年 8 月までの過去 3 力年程度の期間に公刊・発表された図書・論文の執筆者（規程では会員に限って いませんが, 当面は日本地理学会会員を対象にします)

2. 推薦方法

自薦または他薦

3. 推薦に必要な提出書類の内容 (形式は自由, 冒頭に優秀賞推萀と明記すること)

ア）受賞候補者の氏名

イ）受賞対象図書または論文のリスト 図書は著者名・書名・出版社名・総ページ・刊行年を, 論文は著者 名・発表年・論文タイトル・掲載誌名・巻・号・ページを明記して下さい. 論文（国際的な学術誌に揭載され たものを含む）の場合は，複数の論文をあわせて業績とすることができます，共著の図書や論文であっても， 主たる著者であることが明らかなすのは対象にすることができます.

ウ）推薦理由（400 字以内）

工）推薦者の氏名・連絡先

(第 3 表紙へつづく) 
4. 推薦書類の提出先

テ113-0032 東京都文京区弥生 2-4-16 学会センタービル

日本地理学会事務局 学会賞受賞候補者選考委員会 あて

5. 推萀書類受付締切り

2003 年 12 月 20 日（土）必着

なお，選考の過程で必要な場合には，対象となる業績（図書・論文など）を推薦者から提出していただく場 合があります.

(参考 : 規程加らの抜粋)

日本地理学会賞に関する規程 第 2 条 2. 優秀賞は，当該年度の 8 月までの過去 3 力年の期間に公刊された図 書・論文の執筆者を対象とする．受賞者の数は，原則として毎年度若干名とする.

日本地理学会投稿規定，地理学評論和文原稿執筆要領，閲読に関する内規などは，『日本地理学会会員 名簿 (2001)』166 ページ，167〜175 ページ，177 ページに掲載されています. 御参照下さい.

編集専門委員会—高阪宏行 (委員長) 田瀬則雄 (副委員長) 菊地俊夫 (副委員長) 矢ヶ㠃典隆
(副委員長) 青木英一 石川義孝 Juha Uitto 上野健一 梅本 亨
大内俊二 岡 秀一 岡橋秀典 小口 高 小野寺 淳 加賀美雅弘 川口太郎
菅野峰明 Victor Savage 島田周平 鈴木啓助 鈴木力英 須山 聡
関戸明子 高木彰彦 高田将志 高橋重雄 高橋日出男 竹内裕一 田原裕子
手塚 章 友澤和夫 中川 正 西野寿章 西原 純 朴 倧玄 林 和生
日野正輝 廣松 悟 藤田直晴 Simon Potter Larry S. Bourne
Mary G. McDonald 松井圭介 松倉公憲 水野 勲 溝口常俊 村山祐司
Ma和 紀 山川修治 山本 充 渡邊真紀子 渡辺満久 (書記) 細井久恵

本誌の刊行にあたっては平成 15 年度日本学術振興会科学研究費補助金（研究成果公開促進費）の助成 を受けた。

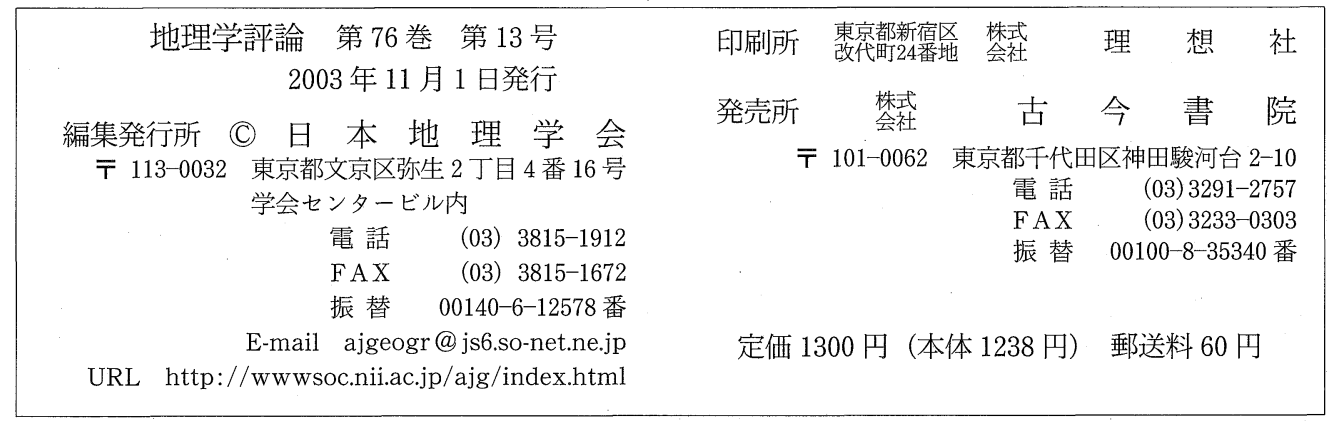

本会へ入会を希望される方は，はがきもしくは電話，FAXにて上記の日本地理学会事務局までご連絡 下さい．折り返し，入会申し込み用紙をお送りいたします． 